\title{
History, ethnicity, and policy analysis of organic farming in Japan: when "nature" was detached from organic
}

\author{
Yoshitaka Miyake(D) and Ryo Kohsaka * (D)
}

\begin{abstract}
The ratio of organic farming in Japan stagnated in terms of area and involved farmers despite the richness in history symbolized in terms such as the Fukuoka methods or the more recent Teikei. This paper first reviews the historical development of Japan's organic agriculture from the 1930s (first epoch), regarding Japanese ethnicity and its roots and relationships to nature. Based on this analysis, we critically evaluate policy development from the 1990s (second epoch). Here, we provide potential explanation for the low ratio of organic agriculture in Japan. By combing the conceptual analysis of ethnicity and organic movements, the underpinning factors that underlie the development of organic farming are analyzed both from historical and cultural contexts. Natural farming is a separate individual practice in Japan, with its own philosophical backgrounds. This initial 1930s terminology of "natural farming" or shizen nōhō (自然農法) was translated into yūki nōgyō (有機農業) in the 1970s. This review claims that the meaning of organic agriculture got too narrow to promote organic agriculture with the governmental intervention and standardization from the 1990s. The initial phase of yūki nōgyō also had such a problem as the concept became increasingly institutionalized through government standardization and policy from the 1990s. Currently, at the conceptual level, the linkage to nature, i.e., "shizen," is confined into "non-use of chemical components" through formal institutionalization, and the ethnic elements or philosophical and historical roots are neglected. Similar phenomena of "commodification of organic farming" are widely known in matured markets in the USA and Europe, but the discrepancy of "nature" and "organic" agriculture is particularly also observed in contemporary Japan.
\end{abstract}

Keywords: Organic agriculture, Organic agricultural policies, Fukuoka, Natural farming, Teikei, Innovation transition, Japan

\section{Introduction}

Japan's organic agricultural history extends over 80 years, with well-known concepts such as the Fukuoka method or the more recent Teikei from the early twentieth century and the 1970s, respectively. The former derives from internationally recognized pioneers such as Masanobu Fukuoka (Fig. 1) [2] and is internationally known as the Fukuoka method of natural farming. More recently, the Teikei movement, which involves consumers

\footnotetext{
*Correspondence: kohsaka@hotmail.com

Graduate School of Environmental Studies, Nagoya University, Furo-Cho Chikusa-Ku, Nagoya City, Aichi 464-8601, Japan
}

discussing prices and products with producers in advance, originated in Japan and became internationally well-known. The movement is later associated with organic producers and consumers to strengthen the producer's power over product sales. These methods represent the historical efforts of the pioneering and following farmers and other stakeholders to develop an ethnic way of organic agriculture in Japan.

Despite these rich experiences, the organic sector suffers growth difficulties in contemporary Japan, e.g., while the farmland share of organic agriculture is $1.4 \%$ worldwide, that in Japan is $0.2-0.5 \%[3,4]$, being lower than

(c) The Author(s). 2020 Open Access This article is licensed under a Creative Commons Attribution 4.0 International License, which permits use, sharing, adaptation, distribution and reproduction in any medium or format, as long as you give appropriate credit to the original author(s) and the source, provide a link to the Creative Commons licence, and indicate if changes were made. The images or other third party material in this article are included in the article's Creative Commons licence, unless indicated otherwise in a credit line to the material. If material is not included in the article's Creative Commons licence and your intended use is not permitted by statutory regulation or exceeds the permitted use, you will need to obtain permission directly from the copyright holder. To view a copy of this licence, visit http://creativecommons.org/licenses/by/4.0/. 


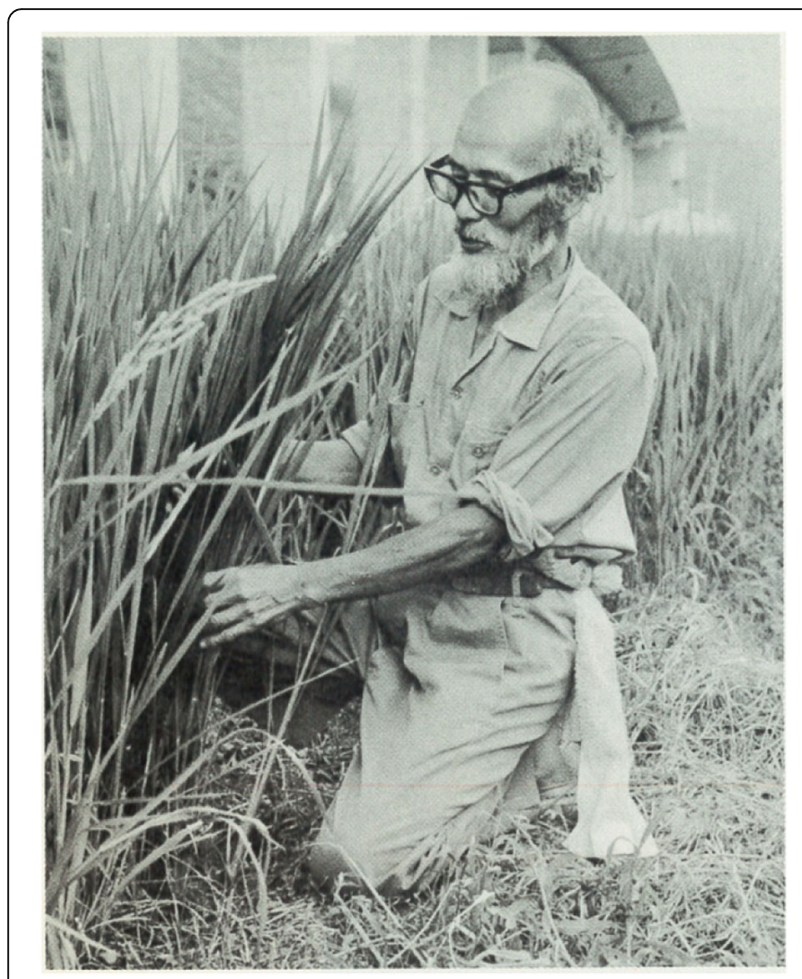

Fig. 1 Masanobu Fukuoka with fruiting rice. Reproduced from Natural Farming: Theory and Practice of Green Philosophy. Tōkyō: Jiji Press Publication [1]

those in the advanced economies of Europe and North America, and countries in the East Asia region including South Korea, where the rate is $1.2 \%$ [4]. To counter this issue, the Japanese government started bringing in regulation in the 1990s and has developed a comprehensive policy menu that supports organic farmers and their networks to improve agricultural technologies and sales [5].

This study reviews the historical development of Japan's organic agriculture from the 1930s considering its ethnicity, roots, and relationships with nature. The study considers a first epoch reflecting the development from the 1930s to the 1980s, and a second epoch from the 1990s, critically and conceptually evaluating policy development and finding a reason for the low ratio of organic agriculture. Although the organic agriculture sector has tried to develop a mutual relationship between farmers and consumers through natural farming, the Teikei system, and consumer cooperatives, policy has not focused on these contributions. From our review, it is clear that the linkage to nature "shizen" is somewhat restricted to "non-use of chemical components," and the ethnic elements or philosophical and historical roots have been disregarded. Similar phenomena as "commodification of organic farming" are widely known in matured markets in the USA and Europe. However, there is a discrepancy between "nature" and "organic" farming in contemporary Japan.
The reasons for the low conversion rate are complex, with social, economic, and environmental components. Here, although we are aware of the technical elements related to the non-use of pesticide and amount of harvests $[6,7]$, we focused on the history and conceptual elements to comprehensively assess the issue in Japan. We first reviewed the conceptual roots and development of Japanese organic agriculture. Then, we analyzed the underlying causes behind contemporary policies. Based on the comparison between the first and second epoch, the factors underlying the development of organic farming were analyzed both from the historical and cultural perspectives.

\section{Development and policy of organic agriculture in Japan} Organic agriculture development in Japan

We categorized the development of Japanese organic farming into two periods: 1930s to 1980s and the contemporary period (since the 1990s). Conventionally, the epochs for Japanese organic agriculture are separated by the introduction of the Act on Promotion of Organic Agriculture in 2006 [2]. However, separating the periods at the beginning of the 1990s, when the organic agriculture regulations started, can help to explain the role of government policy on organic agriculture. As the government created regulations in the 1990s, a series of labeling policies deepened the cultural deadlock, ignoring the historical linkage that farmers and consumers formed with nature and organic food.

Modern organic agriculture started in Japan in the 1930s [2]. Since then, the Japanese developed their unique and well-regarded ethnic methods and philosophy of organic agriculture (Table 1).

The first epoch began with pioneer grass-root movements. The pioneers of Japanese organic agriculture independently practiced and demonstrated their methods from the 1930s [2]. The most prominent pioneers were Mokichi Okada, a religious leader, and Masanobu Fukuoka, an agricultural philosopher. Okada encouraged the use of natural power without chemical fertilizers and pesticides. In contrast, Fukuoka raised the principles of avoiding plowing, fertilizers, pesticides, and weeding (Figs. 2 and 3). For this philosophy and practice, Fukuoka is still internationally regarded as an organic food pioneer. He thought that he would find essential elements and easier farm work as he omitted common agricultural technology elements one by one [2]. These initial practices, called "natural farming" or shizen nōhō (自然農法) in Japanese, respected how nature supports crop production and promoted the link between food and health.

Around the WWII period, the use and mobilization of resources were restricted, which was also true for natural farming. Fukuoka worked for the Kōchi Agricultural 
Table 1 Practice and philosophy of organic agriculture in Japan

\begin{tabular}{|c|c|c|c|c|}
\hline & $\begin{array}{l}\text { Natural farming } \\
\text { (shizen nōhō) }\end{array}$ & $\begin{array}{l}\text { Organic agriculture } \\
\text { (yūki nōgyō)/teikei }\end{array}$ & Consumer cooperatives & \multirow{2}{*}{$\begin{array}{l}\text { Government policy and standardization } \\
\text { The Second Period (since the 1990s) }\end{array}$} \\
\hline & \multicolumn{3}{|c|}{ The First Period (1930s to 1980s) } & \\
\hline Practice & $\begin{array}{l}\text { No pesticide nor } \\
\text { fertilizer } \\
\text { No tillage } \\
\text { Self seed collection } \\
\text { Crop rotation }\end{array}$ & $\begin{array}{l}\text { Production of various crop types } \\
\text { All products to be consumed } \\
\text { Price fixed through the } \\
\text { discussion by producers and } \\
\text { consumers } \\
\text { A group will not be too large by } \\
\text { forming new groups. }\end{array}$ & $\begin{array}{l}\text { Producer groups } \\
\text { Decreased use of food } \\
\text { additives } \\
\text { and chemicals } \\
\text { Exclusion of socially } \\
\text { problematized chemicals } \\
\text { Decreased amount of } \\
\text { pesticide } \\
\text { Inspection of pesticide } \\
\text { residues }\end{array}$ & $\begin{array}{l}\text { Regulation on chemical fertilizer, } \\
\text { pesticide, and genetically modified } \\
\text { material }\end{array}$ \\
\hline Philosophy & $\begin{array}{l}\text { Respect for nature } \\
\text { Phenomenology } \\
\text { with fire, land, and } \\
\text { water } \\
\text { Keeping land clean } \\
\text { Link among nature, } \\
\text { food, and health } \\
\text { Symbiosis with } \\
\text { nature }\end{array}$ & $\begin{array}{l}\text { Mutual help and understanding } \\
\text { between farmers and consumers }\end{array}$ & $\begin{array}{l}\text { Anxiety about food } \\
\text { additives and remained } \\
\text { pesticide } \\
\text { Registered producers } \\
\text { Production methods are } \\
\text { open. } \\
\text { Communication between } \\
\text { producers and consumers }\end{array}$ & Avoid the confusion of labels \\
\hline
\end{tabular}

Experiment Station and researched plant pathology. After Okada started to discuss natural farming and food in 1935, the National Police Agency investigated Okada to stop his healing methods [8]. By the end of WWII, he evacuated from Tokyo. Later, natural farming contributed to the technological development of organic agriculture and played a major role in the development of Japan's organic agriculture movements [2].

After WWII, the Japanese rural society and policy circles pursued intensive agriculture and increased food production. The harmful impact of chemical pesticides and food poisoning concerned both citizens and specialists $[2,9]$. This caused the formation of the Japan Organic Agriculture Association, which introduced yūki nōgyō as the translation of "organic agriculture" in 1971. The 1970s also saw the development of the Teikei

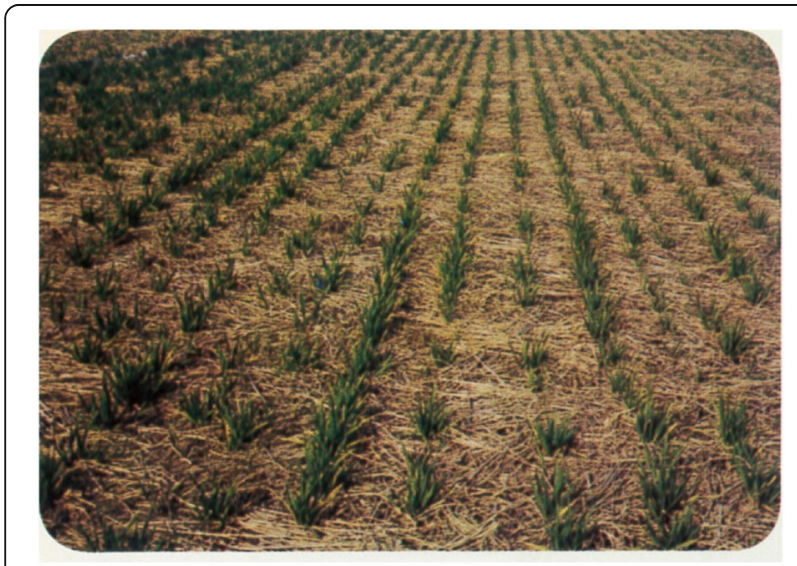

Fig. 2 No-plowing directly seeding wheat field covered with straws from the previous seasons. Reproduced from Natural Farming: Theory and Practice of Green Philosophy. Tōkyō: Jiji Press Publication [1] system among organic producers and consumers. They did not only form a buy-sell relation, but also "a mutual relation based on trust" integrating fundamental market functions [9], p. 2, e.g., in the Teikei system, the producers and consumers decide in advance which products to produce, their quantity, and prices [2]. Thus, the development of the Teikei system caused "the first boom of organic agriculture" [9], p. 2.

In the 1980s, "the second boom of organic agriculture" rose as consumer cooperatives increased the sales of crops produced with decreased use of food additives and chemicals [2]. These organized producer groups started the exchange with urban consumers and, as the sales of agricultural products with less food additives and chemicals increased, consumers became confused over product labeling such as "no chemical" instead of "organic" [2].

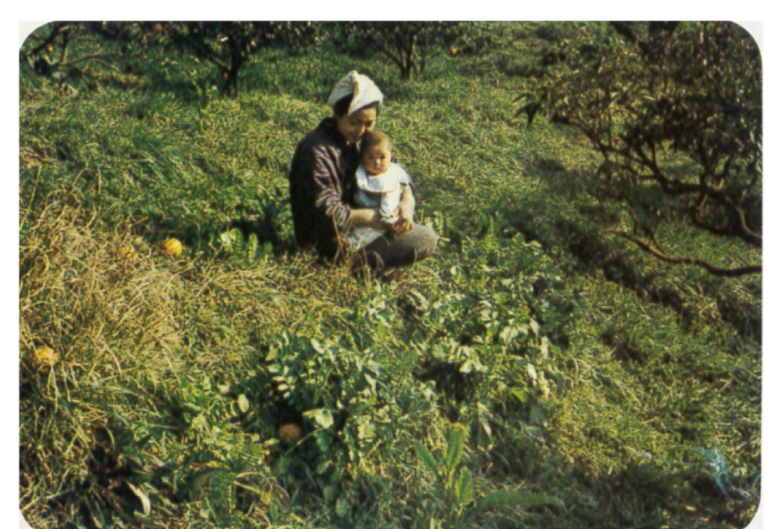

Fig. 3 Vegetables along a path. Reproduced from Natural Farming: Theory and Practice of Green Philosophy. Tōkyō: Jiji Press Publication [1] 


\section{Current organic agricultural policies in Japan}

In 1989, as the National Diet and other governments became interested in organic agriculture as a policy objective for rural development under future trade agreement from the Uruguay Round, the Japanese government started a concrete attempt by establishing the Organic Agriculture Management Office [2]. This started the new epoch (from the 1990s) with a series of regulations and policies. First, the central and local governments focused on fixing the definition of organic agriculture. In 1993, reflecting the social demand to clear the confusion about labels, Ministry of Agriculture, Forestry, and Fisheries (MAFF) implemented the Special Labeling Guideline for Produce Related to Organic Agricultural Products among Others. This further developed into the introduction of the Japan Agricultural Standard (JAS) for Organic Food instituted in 2001.

JAS started in 1950 as a legal regulation about the standards for agricultural products and food [2], and it stipulated the rules of food standards and the prevention of perjury to solve the post-war food crisis. Around the 1990s, increasing complexity in the food system brought about quality food with high surplus value. This added to the confusion in the system, required labeling regulation on food with high surplus value, and caused the revision of the standard in 1999. The revision included JAS for Organic Food [2], which attempted to solve the confusion of the labels on organic and other healthy food. According to these renewed standards, producers and companies must use the JAS label to sell agricultural products as "organic" [2]. JAS for Organic Food followed the increasing trend of organic food trade and rapidly followed the regulation that resulted from the negotiation in the Codex Alimentarius Commission ${ }^{1}$ from 1991 to 1999 [2], taking the ideas of international standardization and third-party certification. In this approach, the certifying bodies check the documents prepared by the applicants to prove that they follow the government-decided JAS.

JAS requires organic agriculture to stop the use and infusion of chemical fertilizers and pesticides, as well as genetically modified material, and is process-based, i.e., farmers and food producers document each stage of the production such as cultivation, processing, and storage but they do not have to prove the lack of certain chemical materials through the direct test of the products.

European countries initially employed the system of third-party certification for organic food production, and the Codex Alimentarius Commission accepted this system as part of the international standards in 1999.

\footnotetext{
${ }^{1}$ The Codex Alimentarius Commission was established by the Food and Agriculture Organization and World Health Organization in 1963 to decide the international standards and codes over food [10].
}

Therefore, considering that European countries and the USA began implementing these ideas in the 1980s, JAS for Organic Food, starting in 2001, very quickly adopted the western ideas of the certification as it legalized the system and devised the implementation rules and institutions.

Eventually, JAS alleviated the labeling confusion over organic food [2]. However, Nakajima claimed that farmers and other stakeholders did not think that JAS was so acceptable [2]. JAS does not provide clear guidance for farmers to shift from environmentally friendly agriculture with less chemical use to organic agriculture, because organic agriculture was not the primary policy target, just one type of environmentally friendly agriculture. Moreover, although JAS emphasizes the regulation of chemical fertilizers and pesticides, it lacks the care kept by the ethnic tradition of Japanese organic agriculture (Table 1), ignoring the historically developed link among nature, producers, and consumers at a local or grass-root level. Therefore, the standards became institutional but less powerful to spread organic agriculture in Japan and did not become a strong drive to increase organic agriculture [2]. We argue that "nature" was detached from "organic" through this transition. Therefore, JAS for Organic Food was developed in a rather "topdown" manner, which contrasted with European countries. In addition, because JAS could certify foreign production, this increased to $2,121,487$ tons in 2017 [11], much larger than the domestic production (69,169 tons).

To promote organic agriculture, the League of the Diet Members for Organic Agricultural Research formed among the Liberal Democrats in 1987, and MAFF started the Organic Agriculture Management Office in 1989. Furthermore, the Japanese government enacted the Act on Promotion of Organic Agriculture in 2006 (Fig. 4). The law claimed governmental responsibility for the development of organic agriculture with local governments and private actors [2]. To promote the act, the Japanese government announced the Basic Guideline on Promotion of Organic Agriculture in 2007, and the second and current Basic Guideline has been effective since 2014 [2, 5]. The first Basic Guideline did not succeed because the government of the Democratic Party of Japan canceled the guideline's feature policy, the model town project for organic agriculture in 2009 [2, 12]. The second Basic Guideline had the following goals: (1) increasing the share of organic farmland in the country to $1 \%$, (2) establishing the technological system, (3) establishing the extension system, (4) increasing consumer understanding, and (5) establishing governmental promotion from national to local levels [5].

As the law and guideline result in policies to promote organic agriculture, they are supposed to supplement JAS. The Japanese government provides policies to help 


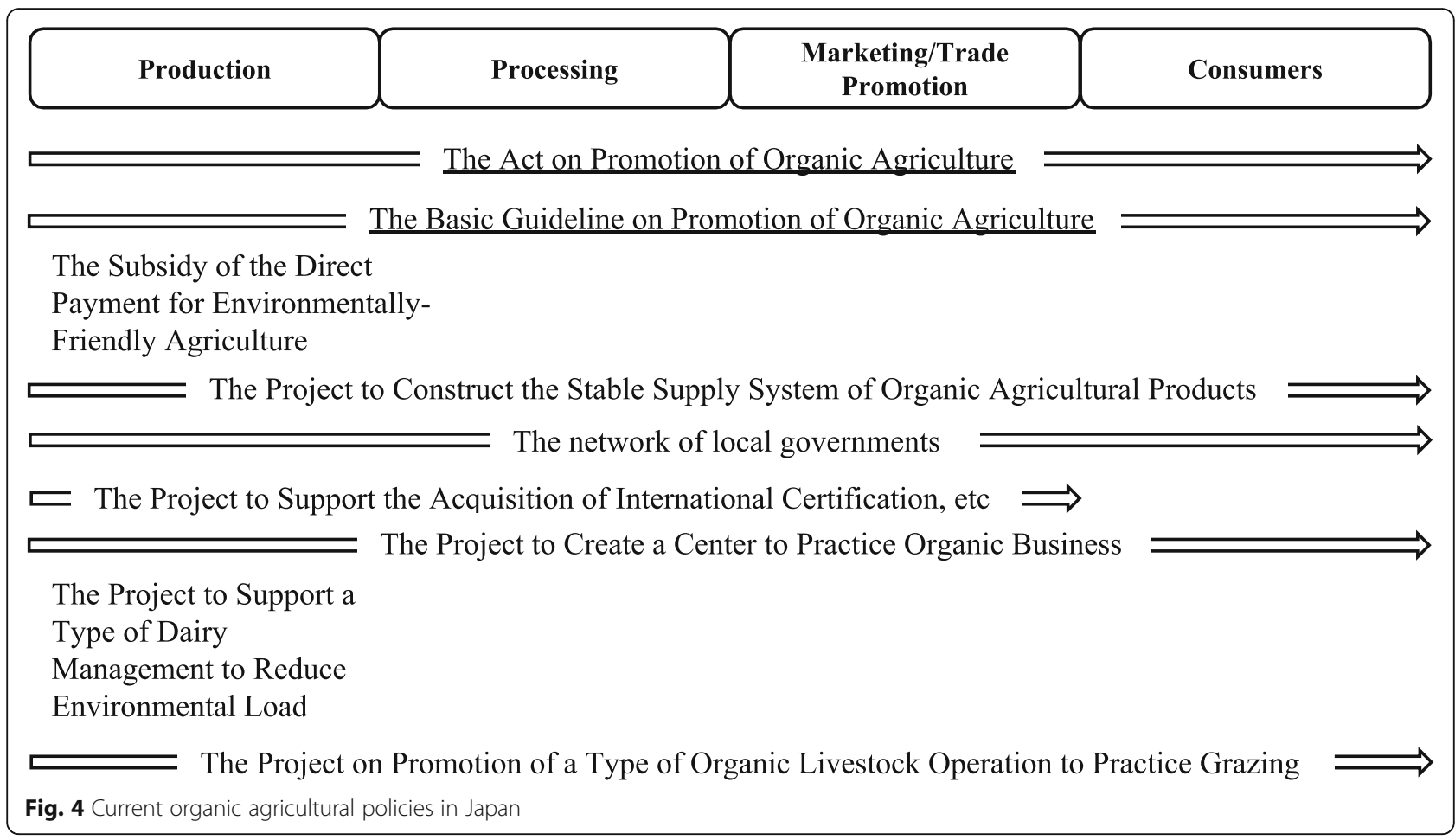

in various aspects of organic agriculture from the financial support of organic farmers to the network of local governments. As direct financial support for organic agriculture, the Subsidy of the Direct Payment for Environmentally-Friendly Agriculture includes the payment for implementing organic agriculture, i.e., 8000 yen per 10 acres [5]. Furthermore, targeting the increase of organic products, the government conducts policies such as Project to Support the Acquisition of International Certification and subsidizes farmers and food processors to be certified with JAS for Organic Food. This program also includes subsidies to help the recipients with product development, international business negotiation, and the lease of agricultural machines.

The Project to Create a Center to Practice Organic Business currently supports 26 areas in Japan as the farmers try activities such as the creation of organic farmers' network and the provision of training fields for beginning farmers [5]. Moreover, the project supports information exchange between organic farmers and related businesses and buyers and was included in the Project to Construct the Stable Supply System of Organic Agricultural Products [5], which supports the negotiation with businesses on the demand side, educational activities on organic agriculture and certification, and the network link to local governments.

In 2019, the network of local governments included 17 municipalities and eight prefectures [5]. This network tries to provide a platform of information exchange among local governments and private companies and targets municipalities interested in development of organic agriculture and prefectural governments to support interested municipalities.

Moreover, the government promotes organic livestock operations [5]. The Project to Support a Type of Dairy Management to Reduce Environmental Load subsidizes dairy production to produce organic feed $(45,000$ yen/ hectare). Another policy, Project on Promotion of a Type of Organic Livestock Operation to Practice Grazing, supports the attempts to find solutions for technological issues affecting organic feed production and use and to increase organic grazing livestock production. Therefore, the Japanese government provides a comprehensive policy menu for organic agriculture covering producers, related businesses, and local governments.

\section{Discussion}

We applied the innovational process by Geels and Schot (2007) to highlight the processes at different levels and identify gaps [13]. Japanese policies for organic agriculture such as JAS, influenced by the EU standards, are the process identified as policy (Fig. 5). In Japan, the policy concept of "organic" was defined and originated at the "meso level" without much discussions linking to the bottom level (at the "niche" level or with the linkage to "nature"). At a micro or niche level, these practices occur at a smaller scale and have a history and spirituality of linkage to nature (Fig. 5). However, they cannot be easily institutionalized with standards and criteria partially owing to their diversity. At this "niche level," farming methods do 


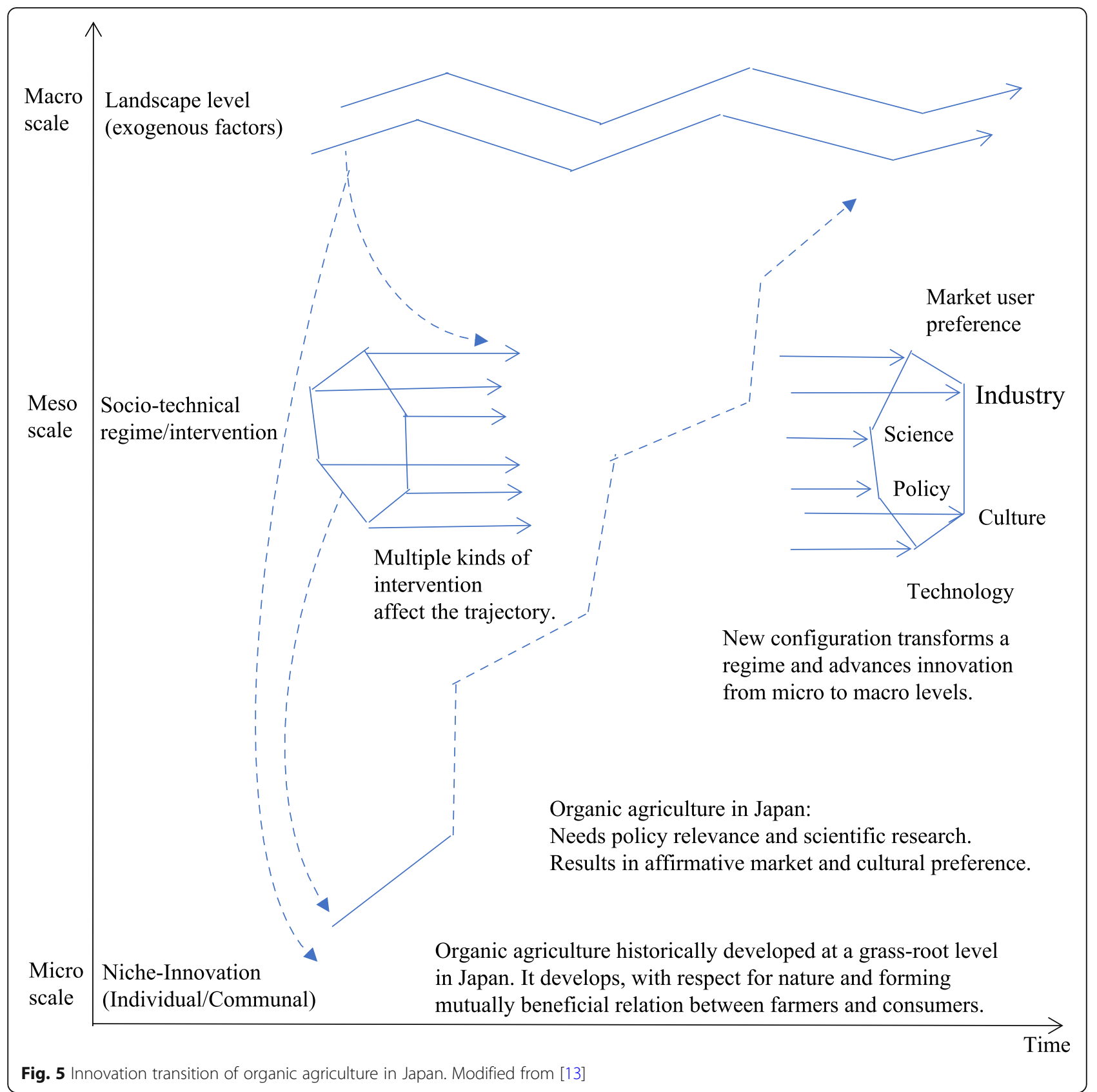

not only frequently become standardized, but also include the respect for nature and the mutually beneficial relation between farmers and consumers. One obvious gap of organic agriculture in Japan is bridging between the micro and meso levels (Fig. 5) [13].

Currently, "organic" does not fully reflect the rich history, diversity, and ethnical grass-roots, as the concept evolved in a top-down manner. This presents advantages for legal institutionalization and simplicity but slowed the spread of organic agriculture. Future policy improvements and other types of intervention might be necessary to embrace these traditions, which would strengthen the producer-consumer relation and their organization in the development of organic agriculture. This would demand contemporary science to justify organic agriculture and related policies, and these organizational and scientific efforts could pursue efficient but democratic development of Japan's organic agriculture. Then, the policies and certifications could be environmentally and culturally justifiable.

Currently, the introduction of the Participatory Guarantee System (PGS) is considered within the government to ease the burden of small farmers and link farmers and consumers in the development of organic agriculture at 
a local level. However, it was not adopted for the fiscal year 2020 [14]. According to the International Federation of Organic Agriculture Movements, "Participatory Guarantee Systems are locally focused quality assurance systems. They certify producers based on active participation of stakeholders and are built on a foundation of trust, social networks and knowledge exchange" [15]. Organic Shizukuishi became qualified as Japan's first PGS in 2018 [Organic Shizukuishi member, personal communication, December 26, 2019]. According to a member, the fee to be qualified as a PGS farmer was slightly over 7500 yen, much cheaper than that to be certified under JAS (about 220,000 yen). This group had 22 members including six local farmers. As Organic Shizukuishi had diverse members such as a nutritionist and an inn owner, they could have multiple types of stakeholders participating in the on-site inspections and other events. Besides the monthly study meetings, they were engaged in community development activities such as the reactivation of abandoned farmland and food education at a nursery school.

While government policies encourage the network and negotiation with the companies on the demand side, through the lens of ethnic tradition, farmers and companies would seek for mutual benefit and understanding to sustain organic agriculture and nature.

To fully appreciate nature, the Japanese government could create policies to test the comparative difference between conventional and organic agriculture. In Germany, Thünen Institute conducted a comprehensive systematic review about this comparison [16] and found significant differences in water quality, soil fertility, biodiversity, and climate change prevention in terms of greenhouse gas emission from soil. In addition, several Japanese studies showed significant differences in biodiversity [17] and the emission of carbon dioxide from farmland [18]. To some extent, the Japanese government promotes organic agriculture as it mentions that organic agriculture reinforces the measures for climate change and biodiversity protection [19]. However, it does not emphasize research as a policy priority in the same way as Germany's national forward-looking strategy [20]. Thus, the Japanese government could increase the priority of scientific research, including the comparison between conventional and organic agriculture, which would justify policies for organic agriculture and better persuade both producers and consumers. In addition, with better scientific data and research, organic agriculture would not only address the demands to alleviate environmental issues but also contribute to the development of a "sharing economy" [21]. Sharing economy represents the collective access and sharing in a network-based community and contributes to ethical consumption for environmental justice. This would further Japan's ethnic philosophy of organic agriculture.

\section{Conclusion}

Organic agriculture first developed in Japan with the prominent pioneers in the 1930s, rooted in their own practical philosophy and practices. Later, in the postWWII period, the Teikei system tried to secure the mutual relationship between organic producers and consumers since the 1970s [2]. From the 1990s, the government started to bring in regulations over organic agriculture. JAS trivialized the ethnic tradition and disintegrated the conceptual and socio-environmental linkage of Japanese organic agriculture, a process that we described as "nature" detached from "organic." Promotion policies such as the 2006 Act would function well once the contradiction between the ethnic tradition and the standards is resolved. For this purpose, the Japanese society will need to reevaluate these practices, linking the origins in natural farming, and possibly converting and reviving this practice in contemporary society, involving producers, retailers, and consumers. Such changes could be "niche" innovation but has the potential to lead to larger changes. The realignment and innovation of policies and the active introduction of scientific research and knowledge could help to develop organic agriculture in Japan, keeping its historical ethnic roots in the development.

Japan needs to work on the improvement of policies from production to consumption, employing scientifically and culturally correct measures, and its historical development of ethnic organic agriculture would help to develop in this direction. Japan's organic agriculture shares two urgent social and environmental problems with other countries such as the USA and European countries: capital intensification of the organic sector, "commodification of organic agriculture" such as the increasing presence of supermarkets and discounters on the retail sector, with producers insufficiently prepared to negotiate the prices. With a policy shift focused toward global environmental problems [22], organic agriculture will be the more likely solution for these issues as the producers and consumers become capable actors in the agri-food system. Japan's involvement in these issues will provide a case for further studies.

\footnotetext{
Acknowledgements

The authors thank Dr. Shizuka Hahimoto at the University of Tokyo to inspire and introduce existing studies of the innovation transition.

\section{Authors' contributions}

Yoshitaka Miyake and Ryo Kohsaka coauthored the manuscript. The author read and approved the final manuscript.

Funding

The study for this article was funded by Policy Research Institute, MAFF of Japan as the Commissioned Project on the Policy Science of Agriculture, Forestry, and Fisheries from the year 2018 to 2020: Factors to Facilitate Production and Export of Organic Agricultural Products: Analysis of Status and Trends in EU and Implications for Japan. In addition, the study was
} 
funded by the JSPS KAKENHI Grant Numbers JP16KK0053 and JP17K02105 and DAIKO Foundation (2019).

\section{Availability of data and materials}

There are no data available as is a review article.

\section{Competing interests}

The authors declare no conflicts of interest.

Received: 10 February 2020 Accepted: 29 April 2020

Published online: 03 June 2020

\section{References}

1. Fukuoka M. Natural farming: theory and practice of green philosophy. Tōkyō: Jiji Press Publication; 1976. [in Japanese].

2. Nakajima K. Organic agriculture in Japan: toward the restoration of agriculture and land. In: Nakajima K, T Ōyama, K Ishii and K Kim. The possibility organic agriculture opens: Asia, America, and Europe. Mineruva Shobō: Kyōto; 2015. [in Japanese].

3. Ministry of Agriculture, Forestry, and Fisheries of Japan. Our country's situation over organic agriculture. 2019. https://www.maff.go.jp/primaff/ koho/seminar/2019/index.html. Accessed 16 Dec 2019 [in Japanese]

4. Willer $\mathrm{H}$ and Lernoud J, editors. The world of organic agriculture: Statistics and emerging trends 2019. Research Institute of Organic Agriculture FiBL and IFOAM-Organics International; 2019.

5. Ministry of Agriculture, Forestry, and Fisheries of Japan. The situation over organic agriculture. 2019. http://www.maff.go.jp/j/seisan/kankyo/yuuki/ attach/pdf/index-137.pdf. [in Japanese].

6. Japan Crop Protection Association. Are agricultural chemicals really necessary? 2017. https://www.jcpa.or.jp/qa/a6_17.html. [in Japanese].

7. Japan Plant Protection Association. The research results about the damage from pests and so on in case of cultivation without agricultural chemicals. 1993. http://www.jppa.or.jp/test/houkokusho.html. [in Japanese].

8. Sekai Kyūsei Kyō, ed. The last volume of the light in the East. 1981 [in Japanese].

9. Masukata T. Domestic and foreign trends of organic agriculture and its label standards. Nōgyō Shijō Kenkyū. 1994;2(2):1-11 [in Japanese].

10. Food and Agriculture Organization of the United Nations (FAO). Codex Alimentarius: international food standards. 2020. http://www.fao.org/faowho-codexalimentarius/en/. Accessed 15 Jan 2020.

11. Ministry of Agriculture, Forestry, and Fisheries of Japan. The record of certification by certifying corporations in 2017. 2019. https://www.maff.go. jp/j/jas/jas_kikaku/attach/pdf/yuuki-104.pdf. [in Japanese].

12. Nōgyō Kyōdō Kumiai Shimbun. Continue "The model town project for organic agriculture": the request to Minister Akamatsu for Agriculture, Forestry, and Fisheries. 2009. https://www.jacom.or.jp/archive03/news/2 009/12/news091218-7308.html. [in Japanese].

13. Geels FW, Schot J. Typology of sociotechnical transition pathways. Research Policy. 2007;36:399-417.

14. International Federation of Organic Agriculture Movements (IFOAM). Participatory Guarantee Systems (PGS). n.d. https://www.ifoam.bio/sites/ default/files/page/files/pgs_concept_joaa2012.pdf. Accessed 3 Jan 2020.

15. International Federation of Organic Agriculture Movements (IFOAM). Definition of participatory guarantee systems. n.d. https://www.ifoam.bio/ sites/default/files/pgs_definition_in_different_languages.pdf. Accessed 14 Jan 2020.

16. Sanders J, Hess J. eds. Achievements of organic farming for the environment and society. Thünen Report 65. Johann Heinrich von ThünenInstitut: Braunschweig; 2019. [in German].

17. Katayama N, Osada Y, Mashiko M, Baba YG, Tanaka K, Kusumoto Y, Okubo S, Ikeda $\mathrm{H}$, Natuhara $Y$. Organic farming and associated management practices benefit multiple wildlife taxa: A large-scale field study in rice paddy landscapes. Journal of Applied Ecology. 2019;56:1970-81.

18. Nagano H, Kato S, Ohkubo S, Inubushi K. Emissions of carbon dioxide, methane, and nitrous oxide from short-and long-term organic farming Andosols in central Japan. Soil Science and Plant Nutrition. 2012;58:793-801.

19. Hōjin Yūkinōgyō San'nyū Sokushin Kyōgikai NPO. Let's start organic agriculture! In order to accommodate trainees. Nagano, Japan: Matsumoto; 2016. [in Japanese].

20. German Federal Ministry of Food and Agriculture. Extract from the "organic farming - looking forwards strategy." 2017. https://www.bmel.de/EN/
Agriculture/SustainableLandUse/_Texte/OrganicFarmingLookingForwards. html. Accessed 3 Jan 2020.

21. Hamari J, Sjöklint M, Ukkonen A. The sharing economy: why people participate in collaborative consumption. Journal of the Association for Information Science and Technology. 2016;67:2047-59.

22. Roederer-Rynning C, Matthews A. What common agricultural policy after Brexit? Politics and Governance. 2019;7(3):40-50.

\section{Publisher's Note}

Springer Nature remains neutral with regard to jurisdictional claims in published maps and institutional affiliations.
Ready to submit your research? Choose BMC and benefit from:

- fast, convenient online submission

- thorough peer review by experienced researchers in your field

- rapid publication on acceptance

- support for research data, including large and complex data types

- gold Open Access which fosters wider collaboration and increased citations

- maximum visibility for your research: over $100 \mathrm{M}$ website views per year

At BMC, research is always in progress.

Learn more biomedcentral.com/submissions 